DIW BERLIN

Discussion

Papers
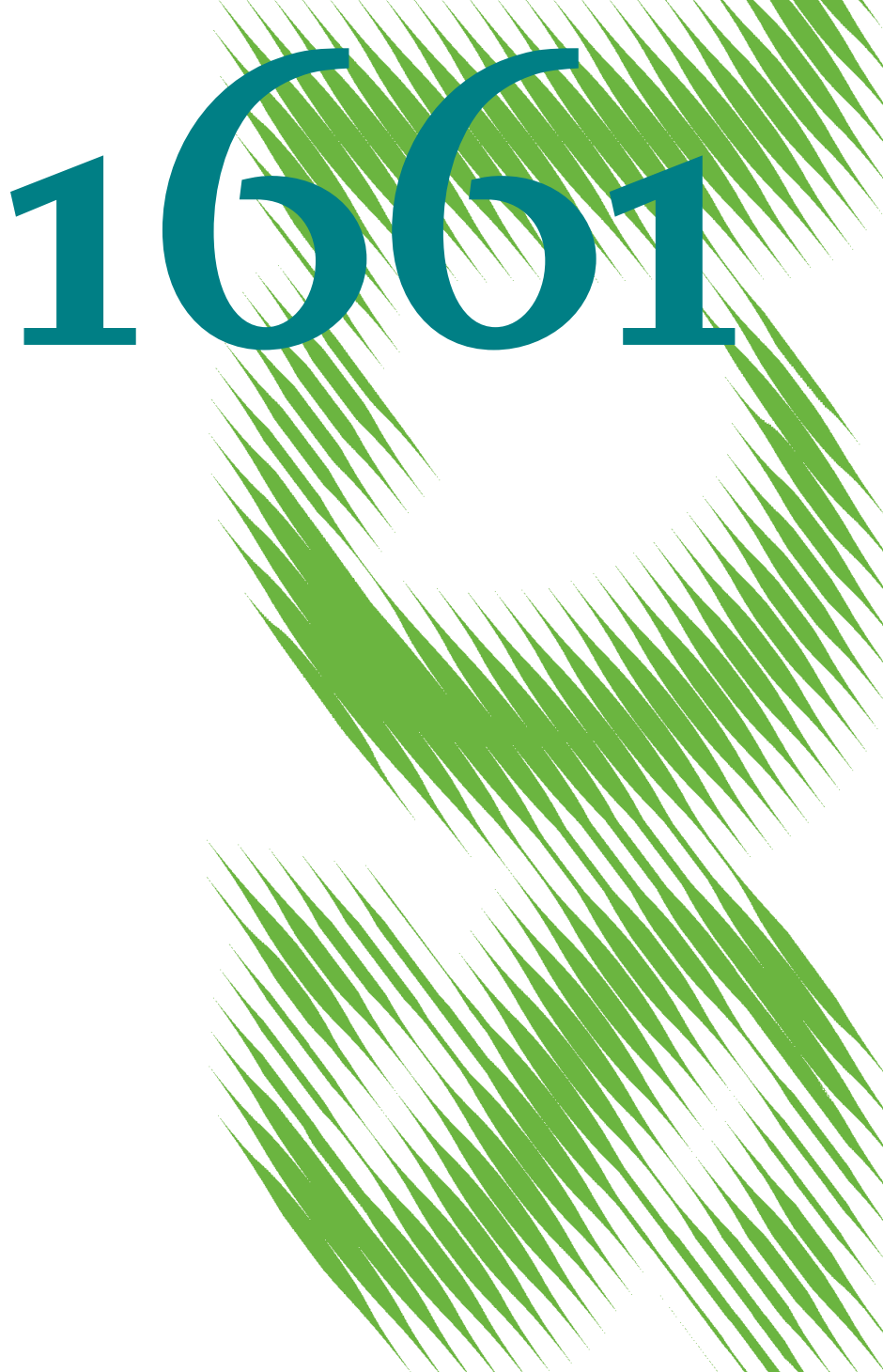

Long Term Growth Perspectives in Japan and the Euro Area 
Opinions expressed in this paper are those of the author(s) and do not necessarily reflect views of the institute.

IMPRESSUM

(C) DIW Berlin, 2017

DIW Berlin

German Institute for Economic Research

Mohrenstr. 58

10117 Berlin

Tel. +49 (30) $89789-0$

Fax +49 (30) $89789-200$

http://www.diw.de

ISSN electronic edition 1619-4535

Papers can be downloaded free of charge from the DIW Berlin website:

http://www.diw.de/discussionpapers

Discussion Papers of DIW Berlin are indexed in RePEc and SSRN:

http://ideas.repec.org/s/diw/diwwpp.html

http://www.ssrn.com/link/DIW-Berlin-German-Inst-Econ-Res.html 


\title{
Long term growth perspectives in Japan and the euro area
}

\author{
Christian Dreger ${ }^{1}$
}

\begin{abstract}
Euro area countries and Japan are confronted with similar challenges. Potential output is on a falling trend in the euro area, and the decrease started well before the financial crisis. In Japan, low output growth is a striking feature since many years, despite the unconventional monetary policy stance and massive fiscal stimulus programs provided by the government. According to a growth accounting exercise based on a Cobb-Douglas production function, the development in both economies can be traced to a weak evolution of TFP. Weak capital deepening is detected especially in the euro area. Driven by high uncertainty with regard to the business cycle, the willingness of firms to undertake investment is only modest and constitutes the achilles heel for a smooth recovery. Both economies are not well prepared to manage the demographic challenges caused by an elderly population. Given that debt-to-GDP ratios are already at record heights, the scope for further demand driven policies is rather limited, especially in Japan. Instead, structural reforms are on the agenda to promote long run growth and a smooth development of the global economy.
\end{abstract}

Keywords: Long run growth, government debt, aging population

JEL: O40, E60, J11

\footnotetext{
${ }^{1}$ German Institute for Economic Research (DIW Berlin), cdreger@diw.de. The author would like to thank the participants of the ADBI/JDZB/GIGA symposium on Post crisis restructuring of the trade and financial architecture: Asian and European perspectives at the Asian Development Bank in Tokyo, Dec 2015 for their helpful comments and suggestions on an earlier version.
} 
Driven by modest GDP growth, the combined weight of Japan and the euro area in the global economy decreased from 30 (1990) to 17 percent, as expressed in constant US Dollars. While the decline of the weight might be overlayed by the integration of emerging markets in the world economy, the loss is also pronounced if only the advanced countries are considered. In terms of this statistic, the share dropped from 50 (1990) to less than 40 percent. The Japanese experience is particularly disappointing. Starting from the early 1990s, the country entered a long period of economic stagnation, after experiencing three decades of fast GDP expansion. The deterioration of growth is the most pronounced downturn observed in the industrial countries since the Great Depression. It was accompanied by bursting price bubbles in asset markets and banking crises due to non performing loans. The lifetime employment system did not provide a buffer, instead, it prolonged the slowdown. To maintain its workforce, companies slashed wages, regrouped workers to low paid activities and became reluctant to recruit young people. To combat deflation, the Bank of Japan cut its interest rate to the zero lower bound. However, although interest rates stay at the bound since almost two decades, prices continued to decline, probably driven by persistent deflation expectations (Ito and Mishkin, 2004). Despite the huge fiscal stimulus programs launched by the government in recent years, a selfsustaining recovery is not in sight, instead, government debt is at new record heights. Because of the weak performance of private consumption and investment, Japan has become more vulnerable against global shocks. For instance, a rise in protectionism practices in the US or an appreciation of the Yen exchange rate against the US Dollar can seriously hit the export performance, with subsequent negative effects on GDP growth.

In contrast to the expectations of many analysts, the introduction of the common currency did not enable the euro area countries to establish a new engine of high and socially inclusive growth to the world economy. Long run growth is on a declining trend in the large member states since decades. Periods of low economic growth and stagnation have been often more persistent than in other advanced countries, including the US. For example, the recovery started with a substantial delay after the burst of the new economy bubble or the global financial crisis. In addition, the financial crisis uncovered serious deficits in the system of macroeconomic governance. The institutional design of the euro area as a monetary union without a fiscal union limited the ability of policymakers to properly respond to the development. The crisis quickly transformed into a crisis of sovereign debt. Investors became more worried about high levels of debt, and reacted by raising interest rate spreads, i.e. they differentiated between the 
risk embedded in the bonds of individual member states. Stand-alone countries were less confronted with rising interest rates, despite the fact that their debt to GDP ratios reached similar levels and were at an increasing trend. Because of the loss of monetary sovereignity and the no bail-out clause, self-fulfilling liquidity crises transformed into solvency crises (De Grauwe and Yuemei, 2014). Several member states became unable to repay their obligations without receiving financial assistance from other members or supranational institutions, such as the ECB and the IMF. Fiscal measures to consolidate government budgets dampened the macroeconomic performance. While the positive effects of consolidated public budgets are typically related to the long run, negative effects dominate over a longer period of transition. At the same time, the ultra-expansionary monetary policy stance did not markedly stimulate GDP. The recent improvement of the business cycle is mainly driven by favorable external conditions, such as the euro depreciation because of a tighter US monetary policy and higher demand by refugees. The deflation risk temporarily decreased mainly due to higher oil prices.

This contribution analyses the long run growth perspectives in Japan and the euro area as well as the challenges ahead. To proceed, Section 2 is devoted to the path of potential output in both regions. Section 3 reviews the evidence on the risks arising from excessive government debt. The demographic trend towards an elderly population is the topic of Section 4. Reform packages for the two economies are discussed in Section 5.

\section{Growth trends in Japan and the euro area}

Driven by fast economic growth over three decades and spurred by financial deregulation in the banking sector, Japan experienced an unprecented boom in equities and real estate prices in the 1980s (Nakaso, 2001). Asset prices rose rapidly, accompanied by excessive bank loans, and an expansionary monetary policy stance to prevent a further appreciation of the Yen after the Plaza Accord. This agreement signed by the G5 countries called for the depreciation of the US-Dollar against major currencies to reduce trade imbalances. At the peak of the real estate boom, the 1.3 square mile of Imperial Palace grounds in the center of Tokyo was estimated to be worth more than all the real estate in California (New York Times, 2008, Oct 18). In the late 1980s, the Bank of Japan raised its interest rate to reduce the size of the bubbles ${ }^{2}$. Probably, the reluctance of the central bank to intervene more quickly deepened the crisis. Stock and

\footnotetext{
${ }^{2}$ It should be noted, however, that the majority of Japanese institutional investors thought that the stock market was not overvalued relative to the fundamentals at that time (Barsky, 2009). This underpins the fact that bubbles are hard to detect in real time.
} 
real estate markets collapsed, leaving Japanese banks with huge amounts of non-performing loans. As the collateral of many firms fell, their credit-worthiness decreased. Driven by increasing overcapacities, the willingness to invest deteriorated. The confidence of private households eroded because of the stagnation of disposable income, the decline of financial wealth and higher uncertainty (Horioka, 2006). Stock and property markets never returned to their precrisis levels. Despite its increase over the recent years, the Nikkei index is still 50 percent below its all time high.

Starting with the burst of the bubble, Japan entered a long period known as the Lost Decades with low output growth and persistent deflation. Several factors might have contributed to the prolonged slump. In the early stages of the development the authorities lacked the expertise and tools required to react in a sufficient way. Even five years after the outbreak of the crisis the Ministry of Finance insisted that no public money would be needed to help banks in financial distress. Only after the Asian crisis in 1997/98, serious measures were implemented to prevent a further deterioration of the banking system. In addition, the relevant actors have been rather reluctant to restructure the economy and undertake reforms.

According to Hayashi and Prescott (2002) the persistent low productivity growth since the Lost Decades is driven by a weak TFP expansion, compared to the earlier period. It might be linked to low incentives of firms to innovate in highly protected markets (Hamao, Mei and Xu, 2007). Ample evidence indicates that the reallocation of resources from less efficient to more efficient firms in the manufacturing sector slowed down in the aftermath of the bubble period (Fukao and Kwon, 2006). To avoid employment losses and bankruptcies, Japanese banks provided further credit to unprofitable and debt-ridden enterprises. In the case of non-performing loans, banks had to write-off existing capital. The fear of falling below the Basle minimum capital standards led many banks to extend credit to insolvent borrowers, the so called zombies. Banks just hoped that these companies could recover or that the government would finally bail them out. The rise of zombie firms reduced competitive pressure in domestic markets and depressed investment and employment even in the more healthy companies (Caballero, Hoshi and Kashyap, 2008). In this sense, the distortion of markets is another argument to explain the long lasting Japanese malaise.

Structural impediments still put a burden on the trend growth rate. As the economy did not sufficiently adjust after the shocks, overcapacities became persistent. Since the burst of the bubbles, GDP has grown by little more than 1 percent per annum. However, because the labor 
force started to decline in the mid of the 1990s, the analysis of labor productivity (output per worker) might be more informative (Figure 1). In terms of productivity, Japan has even outperformed the euro area, but substantially lags behind other economies, including the US. Against this benchmark, the cumulative productivity loss is about 20 percentage points (1990-2016). The current mix of massive fiscal spending and further monetary easing and structural reforms (the so-called Abenomics) did not markedly change the overall picture. In fact, the most relevant component, i.e. the reform pillar has not been launched so far. Various fiscal interventions did not led to a self-sustaining recovery, instead, the public debt to GDP ratio has been pushed to new record heights. Given the demographic trend towards an elderly population, this poses a serious threat to the economy.

-Figure 1 about here-

Like Japan, the euro area countries experienced strong GDP growth in the first three decades after World War $2^{3}$. Fast catching-up was driven by the backlog in demand and the introduction of modern technologies and management practices, mainly adopted from the US. However, the expansion decelerated the closer the economies approached the technological frontier. Since 1990, output increased at an annual rate of 1.6 percent, and output per worker by only 0.6 percent. Like Japan, the monetary union is expected to benefit if the global business cycle improves. Domestic drivers to boost the economy are less pronounced, and have contributed to the slow recovery in the aftermath of shocks. For instance, GDP exceeded the level prior to the financial crisis only recently. In the five years after the crisis, production activities remained below that value. At the same time, the development has been rather unequal across the member states. Driven by strong competitiveness in export markets, Germany recovered rather fast, but Southern members like Italy, Spain, Portugal and particularly Greece have been unable to manage the frontier so far. The increased heterogeneity could undermine the effectiveness of the common monetary policy.

Low productivity growth places a huge burden on faster GDP acceleration. The decomposition of productivity growth reveals that the contribution of capital deepening (capital per worker) is

\footnotetext{
${ }^{3}$ The European monetary union was launched in 1999, and the euro as a common currency was introduced in 2002. In contrast, this paper looks at the performance for a longer period, starting in 1990. Earlier years refer to an artificial construct, where the founding members are aggregated. National currencies are transformed into euro by the official conversion rates.
} 
virtually zero or slightly negative (Table 1). Only in the years prior to the introduction of the monetary union, capital accumulation intensified, implying that capital deepening accounted for much of the productivity advances at that time. In all other periods, the gains are traced to the modest progress in TFP. While the slow TFP expansion is also striking for other countries in the aftermath of the financial crisis, the lack of investment is remarkable especially in the euro area. Despite potential overcapacities in Japan, capital deepening recently improved in Japan, driven by massive public spending in infrastructure. Despite the crisis, the capital stock did not decrease in the US.

-Table 1 about here-

Since the recent years, the economic performance in the euro area is subdued by the efforts of policy strategies to consolidate public budgets, to comply with the rules of the extended Stability and Growth Pact (EU Commission, 2013). The aim of the pact is to ensure that member states implement sound government finances, based on the principle that the policies in one country are relevant for other member states as well.

Fiscal austerity can accelerate trend output, as it can stabilize the expectations of private households and firms regarding the future stance of fiscal policy (Coenen, Mohr and Straub, 2008). For instance, investment activities are based on estimates of the future tax burden. In addition, the demographic challenges of an elderly population might be better managed if public finances are in a relatively healthy state. However, potential benefits from consolidation are normally restricted to the long run. As the long run inevitably emerges from a sequence of short run decisions, the period of adjustment can finally determine the outcome. In fact, the short and medium impacts of consolidation are often negative, in particular in recessions (Perotti, 2011). The impacts appear to be significantly stronger in contractions than in phases of an expansion of the business cycle (Auerbach and Gorodnichenko, 2011). In addition, the losses might be particularly worse at the zero lower bound, as an interest rate channel is suspended. The rates cannot decline further as a response to consolidation. Hence, the improvement of public finances through a reduction of government spending and an increase in taxes likely contributed to the persistent slowdown in many countries and deepened the crisis. Unemployment increased especially in Southern member states, particularly among the young. The longer the period of adjustment is, the higher is the risk to become long term unem- 
ployed, and the larger the losses in human capital. Collective austerity can undermine the EU2020 strategy for sustainable and socially inclusive economic growth.

Austerity measures may also contribute to the decline in public investment. From the perspective of the government, cuts in investment are easier to implement than a reduction of social transfers (Leeper, Walker and Yang, 2010). Cuts in public investment can undermine private investment, as crowding-in effects dominate over longer periods (Dreger and Reimers, 2016). To kick start the economy, the Juncker initiative launched in 2015 aims to boost investment projects in infrastructure over the next few years. Public funding is involved, but due to tight government balances, the bulk should come from private investors. The plan did not overcome the persistent lack in investment so far.

Restrictive fiscal policies are accompanied by an ultra-light stance of monetary policy. As interest rates are already at the zero lower bound or even slightly negative, the ECB switched to unconventional measures implemented by asset purchases at secondary markets. In principle, the expansion of liquidity should increase inflation expectations, and the decline in real interest rates should stimulate the business cycle. However, prolonged periods of low inflation may induce a de-anchoring of inflation expectations from the central bank target (Busetti, Delle Monache, Gerali and Locarno, 2017). As in Japan, the gains from the policy appear to be quite limited so far. The increasing divergence to the tighter monetary policy stance in the US led to a depreciation of the euro, and this side effect stimulates exports from member states. However, the exchange rate channel is hardly sustainable, as other countries may counteract. The boost in liquidity can contribute to the emergence of price bubbles in asset markets, and could reduce the incentives to pursue structural reforms, as the interest burden on government debt is low at the zero lower bound.

\section{Debt restrictions on GDP growth}

Presumably the modest growth performance in Japan and the euro area can be traced to an unsustainable course of public finances. This may provide a rationale for the austerity strategy in the euro area. According to the seminal paper of Reinhart and Rogoff (2009) for 44 countries over the past 200 years, the relationship between public debt and real GDP growth is characterized by strong nonlinearities. The impact of debt is weak for debt to GDP ratios below a threshold of 90 percent. If debt ratios exceed this level, median growth is expected to fall by one percent, and average (mean) growth falls considerably more. Hence, countries with high 
debt should address their fiscal problems in due time to avoid a deterioration of their growth perspectives. The creation of fiscal buffers can be an appropriate approach to compensate for shocks. Checherita and Rother (2010) argued that the turning point, beyond which government debt negatively affects GDP growth is at 90 to 100 percent of GDP in case of the euro area. According to Reinhart, Reinhart and Rogoff (2012) periods of excessive government debt are often long lasting with a duration exceeding 20 years. Hence, the cumulative shortfall in output can be potentially massive. However, the analysis is descriptive and does not investigate a certain direction of causality. Furthermore, whether a certain debt ratio is critical for GDP growth or not depends on the economic conditions. For instance, high debt ratios might not be harmful per se, if the economy under consideration exhibits strong output growth. Because of high revenues, interest payments could be managed even in the high-debt-countries. Empirical evidence for a negative impact of government debt on subsequent GDP growth relationship is rather limited.

In principle, the potential adverse effects from excessive debt might be especially notable for the Japanese economy (Figure 2). Because the government responded to the economic downturn during the Lost Decades by higher spending, the debt to GDP ratio exploded to the highest level among the advanced economies. At the end of the sample, debt reached record heights of 250 percent of GDP, compared to 100 percent in the US and slightly below 100 in the euro area. However, despite the rapid increase in public debt and large budget deficits, the bond yields remained stable. The yields are less sensitive to fiscal debt than in other countries, even after one controls for other determinants, like primary deficits, foreign interest rates and GDP growth (Tokuoka, 2010). The availability of a sizeable pool of household savings due to seniority wage system and bonuses, the presence of large and stable institutional investors, and strong home bias can justify this finding. It should be noted that these factors will likely lose their relevance due to the demographic trends (Section 4).

-Figure 2 about here-

More than 90 percent of public debt are hold by domestic actors who prefer more stable relationships than foreign investors. Private households are highly risk averse and tend to buy domestic assets even if the yields are low (Chen, Imrohoroglu and Imrohoroglu, 2006). Besides that, the real earnings exceed the nominal payments in times of deflation. In addition, large 
institutional investors such as the Government Pension Fund holds sizeable amounts of debt. Hence, the specific structure of creditors provides a buffer against the potential negative effects from excessive debt.

The impact of government debt on the economic performance is also specific for the euro area. While the multiplier is negative for member states in periods of unsustainable debt, the effect diminishes if a broader group of advanced economies is considered. Hence, the participation in monetary union entails an additional risk for its partners (Dreger and Reimers, 2013). Presumably, the finding is caused by gaps in the institutional framework, such as the loss of monetary sovereignity. At the same time, the no bail-out clause forbid member states to assume the debt of others. According to this setting, negative debt spirals can emerge if financial markets have doubts on the solvency of countries, as shown by rising spreads for Italy and Spain. Governments issue debt in a currency beyond their control. Thus, they cannot guarantee to the creditors that they will always have the liquidity to pay off the bonds at times of maturity. Since 2012, the risk for self-fulfilling spirals decreased. In the whatever it takes speech, the ECB announced its willingness to act as a lender of last resort for countries in financial distress. By restoring confidence of international investors, the introduction of the OMT (outright monetary transactions) programme has been an important cornerstone to bring the monetary union back from the brink of disintegration.

\section{Demographic challenges in Japan and the euro area}

Japan and the euro area are faced by the challenges caused by an elderly population, driven by higher life expectancy and low fertility rates. According to the recent UN projections, the development is more striking in Japan (Figure 3). While the share of retirees per worker is 47 percent (2015) it will increase to more than 60 percent in only two decades. In the euro area, the ratio is expected to rise from 34 to 55 percent over the same period. The demographic pressure will be less pronounced in the US.

The aging of the population affects the economy in multiple ways. It will put financial pressure on social security systems because of higher medical expenditures and pensions (Ihori, Kato, Kawade and Bessho, 2005). Elder people need more expensive medical treatment than younger cohorts. The technical progress is a further driver of costs. Besides that, contributions to the pay-as-you-go pension schemes will increase rapidly if the current systems are not reformed. As they raise non-wage labor costs, capital will become more attractive than labor, and pro- 
duction will switch to a more capital intensive mode. The employment response to higher labor costs differs across labor market segments, but tends to be higher in absolute value in labor intensive sectors, routinized and low skilled work. In the absence of higher contribution rates, government expenditures will increase, implying a further deterioration in the debt to GDP ratio. Therefore, reforms are on the agenda, such as policies directed to raise the participation in the labor force, to increase the retirement age or to lower the future level of pensions by decoupling them from the income development.

-Figure 3 about here-

One further aspect is related to the savings rate. Before the Lost Decades Japanese households had one of the highest savings rates in the global economy of more than 20 percent of disposable income. Since then, the savings rate has fallen steadily, and at the end of 2014, it was temporarily negative for the first time since the statistics started. Partially, the decline in the savings rate might be related to the slowdown of economic activity. To maintain their habits, private households need to dissave in periods of low wage and income growth. However, the formation of deflation expectations is expected to work in the opposite direction. Households become more reluctant to spending, as they expect even lower prices in the future, implying that the savings rate should increase.

According to almost all studies, the Japanese savings rate will decrease with the aging of the population. This finding is consistent with the life cycle permanent income hypothesis, see for example Horioka (2006) and Braun, Ikeda and Joines (2009). Evidence based on household surveys suggests that the retired and even the older worker typically dissave. People usually utilize their wealth accumulated during the working period to finance their expenditures after or close to retirement. Therefore, the rate of household savings is expected to fall as retirees account for a larger part of the population.

The prospect of a decline in the savings rate as a long-term phenomenon raises the question whether Japan can continue to cover the government bonds issued in massive volumes each year. Since the retirees might not be willing to finance public debt infinitely, the capacity of the domestic market to absorb further debt could be rather limited. Therefore, the government may be forced to attract more foreign investors by raising interest rates. This might initiate 
debt spirals and can generate financial turmoil in the world economy, together with substantial shifts of main exchange rates. According to the simulation exercise provided by Imrohoroglu and Sudo (2011), unprecedentedly fast growth of TFP will be needed over 10 years, with an average rate of 6 percent per year to eliminate the debt over the next few decades. Since this is very unrealistic, significant improvements in the structure of the government budget are on the agenda. Japan will be forced to enter a phase of fiscal consolidation and to implement structural reforms as soon as possible.

The euro area is likely in a better position than the Japanese economy to manage the demographic changes. The debt to GDP ratio is substantially lower. A home bias is less important, and a marked change in the structure of creditors is not expected. The impact of on aging society on the savings rate is unclear at the euro area level, and even an increase in the savings rate can result. Evidence based on German household surveys suggests that the savings rate strongly responds to demographic trends (Belke, Dreger and Ochmann, 2015). While there is a direct impact arising from of the age structure, an indirect effect will be relevant through the accumulation of real estate and financial wealth. However, the savings rate does not fall with age monotonically, as the life-cycle permanent income hypothesis would suggest. Savings decrease until a minimum is reached, directly after retirement. Starting at an age of about 75 , the savings rate will increase again, probably driven by bequest motives or precautionary behaviour (Bloom, Canning, Mansfield and Moore, 2007). Due to higher life expectancy, elderly people can become seriously ill, and might need financial funds beyond public insurances. Given the demographic projections, a stable or slightly increasing savings rate should be expected over the next two decades for the German economy.

To finance the social security system in an aging society, taxes on labor will increase under the current conditions. However, the tax wedge is already quite high in the euro area compared to other advanced countries. A further rise could be accompanied by major distortions in the labor market and would be an obstacle for a reduction of the high unemployment in many countries. Due to relatively high levels of collective representation, rising labor taxes have been often shifted into higher gross wages (Daveri and Tabellini, 2000). As labour inputs become more expensive relative to capital, companies are encouraged to substitute capital for labour, implying that the marginal product for capital will fall in equilibrium. Because of decreasing returns, the incentives to accumulate capital will probably decline over time, implying lower long-term growth. Nickell, Nunziata and Ochel (2005) found that the difference in the tax burden on labor accounts for approximately one quarter of the difference observed in the 
employment rates between the US and large euro area economies. Higher taxes on labor might worsen the job perspectives of certain groups of the labor force especially vulnerable to unemployment risk, including young and old people, the low skilled and women. Youth unemployment could damage potential human capital, and give rise to a lost generation. Policies to lower the tax burden on labor are thus of high priority for euro area countries, especially since the demographic conditions will likely deepen the problem.

\section{$5 \quad$ Structural reform options in Japan and the euro area}

The Japanese economy faces many challenges and did not recover from the Lost Decades so far. It is unlikely that the current direction of Abenomics can bring the economy back on track. The massive expansion of fiscal expenditures and the unconventional monetary policy pursued by the Bank of Japan will likely extend the period of a weak economic growth with persistent risk of deflation. Negative interest rates might introduce further vulnerability to the banking system. In contrast, a marked acceleration of economic growth is essential to manage the aging of the society. Stronger growth ahead can also reduce the burden from non-sustainable government debt.

Fiscal and monetary policies will not work without the third pillar, i.e. structural reforms. Although measures to raise the participation in the labor force, especially for women and older workers as well as upward shifts in the retirement age can reduce the financial pressure on social security, they are hardly sufficient. Further market-oriented reforms should be implemented to restore confidence of domestic and foreign investors, promote entrepreneurship and innovation and expand trade partnerships through regional or bilateral agreements. The aging of the population presents new business opportunities in many sectors, like biotechnology, robotics, transport, medical infrastructure, leisure and travel, healthcare facilities and education, among others. In addition, imbalances need to be adressed, since the distortions caused by the evolution in the Lost Decades are long lasting. This can include better information and reporting systems with respect to the firms threatened by excessive debt. Unemployment may increase over a period of restructuring. Therefore, policies directed to liberalize the labor market and to facilitate fixed term contracts might be on the agenda. An important issue is to overcome the duality in the Japanese labor market, in which a persistent class of temporary workers are shut out of the regular workforce. Despite increasing profits especially in the export oriented firms, the two-tier labor market system contributed to low wage growth 
and deflation. Higher wage growth might be initiated, for example, by raising the minimum wage and could boost inflation. Stronger economic dynamics can provide the conditions for fiscal reforms, such as the increase in the VAT rate.

In principle, the reform areas for the Japanese economy are also of relevance for the euro area. However, some further comments are in order to address the persistent low productivity growth driven by investment shortages. In particular, the lack of public capital may have restricted private investment in the euro area. For instance, government investments in energy, telecommunications or other network industries have stimulated private investment activities (Pereira and Andraz, 2013). Therefore, the long run performance in the euro area could benefit from further fiscal reforms. On the one hand new programs should shift from simple expenditure cuts and higher taxes to a decrease in public consumption and an increase of public investment combined with structural reforms to stimulate euro area growth. The acceleration of investment can provide a kick start to the economy, while structural reforms should shift the economy on a higher path of long run growth. The expansionary monetary policy can constitute an obstacle in this regard. As interest rate pressure on debt is low, governments might hesitate to implement the reforms in due time. On the other hand, a modified institutional framework should foster higher investment by the member states, in particular for those with healthy public finances and low public investment rates. The exclusion of national co-funding of EU-supported investments programs from the fiscal indicators covered by the Stability and Growth Pact can be a strategy to support the economic performance (Barbiero and Darvas, 2014). The recently introduced European Semester to better monitor fiscal planning at the individual country level should encourage higher investment activities in the member states. In any case, an integrated euro area approach is needed to overcome the risk of stagnation and to achieve high and socially inclusive economic growth. 


\section{References}

Auerbach AJ, Gorodnichenko Y (2011): Fiscal multipliers in recessions and expansions, NBER Working Paper 17447.

Barbiero F, Darvas Z (2014): In sickness and health: Protecting and supporting public investment in Europe, Bruegel Policy Contribution 2014/02.

Barsky R (2009): The Japanese price bubble: A heterogeneous approach, NBER Working Paper 15052.

Belke A, Dreger C, Ochmann R (2015): Do wealthier households save more? The impact of the demographic factor, International Economics and Economic Policy 12, 163-173.

Bloom DE, Canning D, Mansfield RK, Moore M (2007): Demographic change, social security systems, and savings, Journal of Monetary Economics 54, 92-114.

Braun RA, Ikeda D, Joines DH (2009): The savings rate in Japan. Why it has fallen and why it will remain low, International Economic Review 50, 291-321.

Busetti F, Delle Monache D, Gerali A, Locarno A (2017): Trust, but verify. De-anchoring of inflation expectations under learning and heterogeneity, ECB Working Paper 1994.

Caballero RJ, Hoshi T, Kashyap AK (2008): Zombie lending and depressed restructuring in Japan, American Economic Review 98, 1943-1977.

Checherita C, Rother P (2010): The impact of high and growing government debt on economic growth. An empirical investigation for the euro area, ECB Working Paper 1237.

Chen K, Imrohoroglu A, Imrohoroglu S (2006): The Japanese savings rate, American Economic Review 96, 1850-1858.

Coenen G, Mohr M, Straub R (2008): Fiscal consolidation in the euro area. Long run benefits and short run costs, Economic Modelling 25, 912-932.

Daveri F, Tabellini G (2000): Unemployment, growth and taxation in industrial countries, Economic Policy 15, 47-104.

Dreger C, Reimers H-E (2013): Does euro area membership affect the relation between GDP growth and debt? Journal of Macroeconomics 38, 481-486.

Dreger C, Reimers H-E (2016): On the relationship between public and private investment in the euro area, Economic Modelling 58, 154-158. 
EU Commission (2013): Building a strengthened fiscal framework in the European Union: A Guide to the Stability and Growth Pact, European Economy, Occasional Papers 150.

Fukao K, Kwon HU (2006): Why did Japan's TFP growth slow down in the Lost Decade? An empirical analysis based on firm-level data of manufacturing firms, Japanese Economic Review 57, 195-228.

De Grauwe P, Yuemei J (2014): How much fiscal discipline in a monetary union, Journal of Macroeconomics 39 , 348-360.

Hamao Y, Mei J, Xu Y (2007): Unique symptoms of Japanese stagnation: An equity market perspective, Journal of Money, Credit and Banking 39, 901-923.

Hayashi F, Prescott EC (2002): The 1990s in Japan: A lost decade, Review of Economic Dynamics 5, 206-235.

Horioka CY (2004): The causes of Japan's "Lost Decade": The role of household consumption, NBER Working Paper 12142.

Horioka CY (2006): The dissaving of the aged revisited: The case of Japan, NBER Working Paper 12351.

Ihori T, Kato RR, Kawade M, Bessho S-I (2005): Public debt and economic growth in an aging Japan, University of Tokyo, CIRJE-F-372.

Imrohoroglu S, Sudo N (2011): Will a growth miracle reduce debt in Japan? Bank of Japan, IMES Discussion Paper 2011-E-1.

Ito T, Mishkin FS (2004): Two decades of Japanese monetary policy and the deflation problem, NBER Working Paper 10878.

Leeper EM, Walker TB, Yang SCS (2010): Government investment and fiscal stimulus, Journal of Monetary Economics 57, 1000-1012.

Nakaso H (2001): The financial crisis in Japan during the 1990s: How the Bank of Japan responded and the lessons learnt, Bank of International Settlement, BIS Papers 6.

Nickell S, Nunziata L, Ochel W (2005): Unemployment in the OECD since the 1960s. What do we know? Economic Journal 115, 1-27.

Pereira AM, Andraz JM (2013) On the economic effects of public infrastructure investment: A survey of the international evidence, Journal of Economic Development 38, 1-37. 
Perotti R (2011): The austerity myth: Gain without pain? NBER Working Paper 17571.

Reinhart CM, Reinhart VR, Rogoff KS (2012): Debt overhangs: Past and present, NBER Working Paper 18015.

Reinhart CM, Rogoff K (2010): Growth in a time of debt, American Economic Review 100, $573-$ 578.

Tokuoka K (2010): The outlook for financing Japan's public debt, IMF Working Paper WP/10(19. 
Figure 1: Labour productivity in the main advanced countries $(1990=1)$

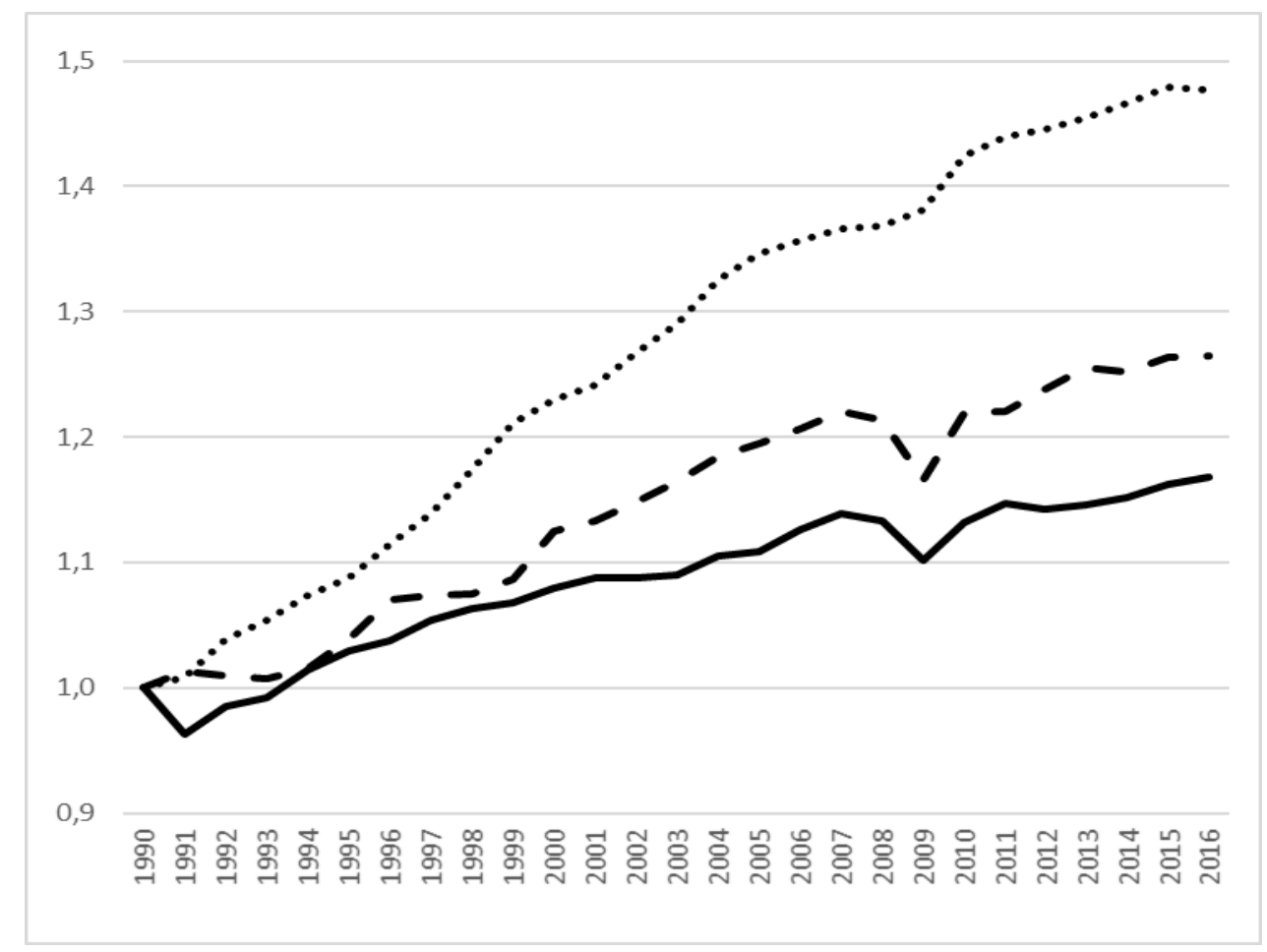

Source: AMECO, EU Commission. Euro area, Japan (dashed) and US (dotted line). 
Figure 2: Government debt to GDP ratio in main advanced countries

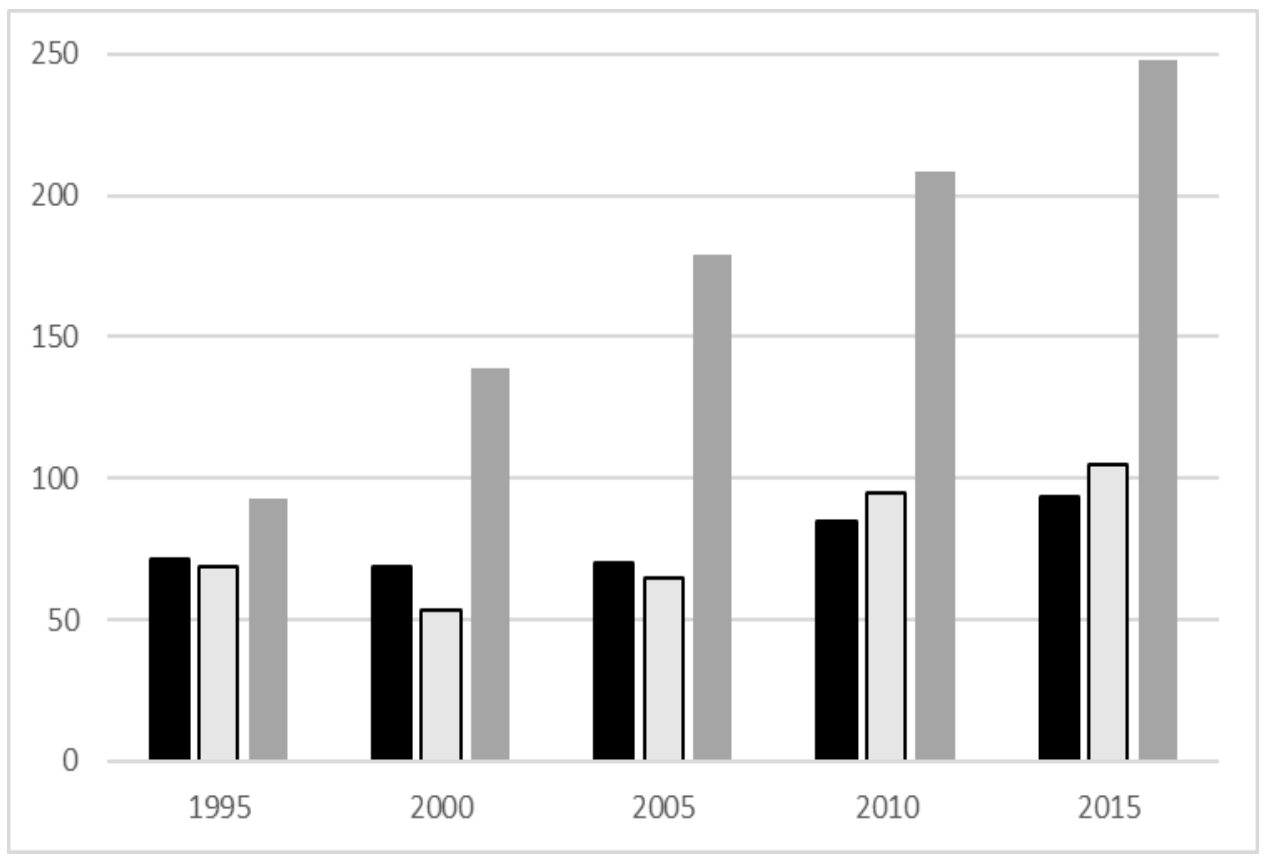

Source: AMECO, EU Commission. Euro area (dark), Japan and US (light). 
Figure 3: Old age dependency ratio in the main advanced countries

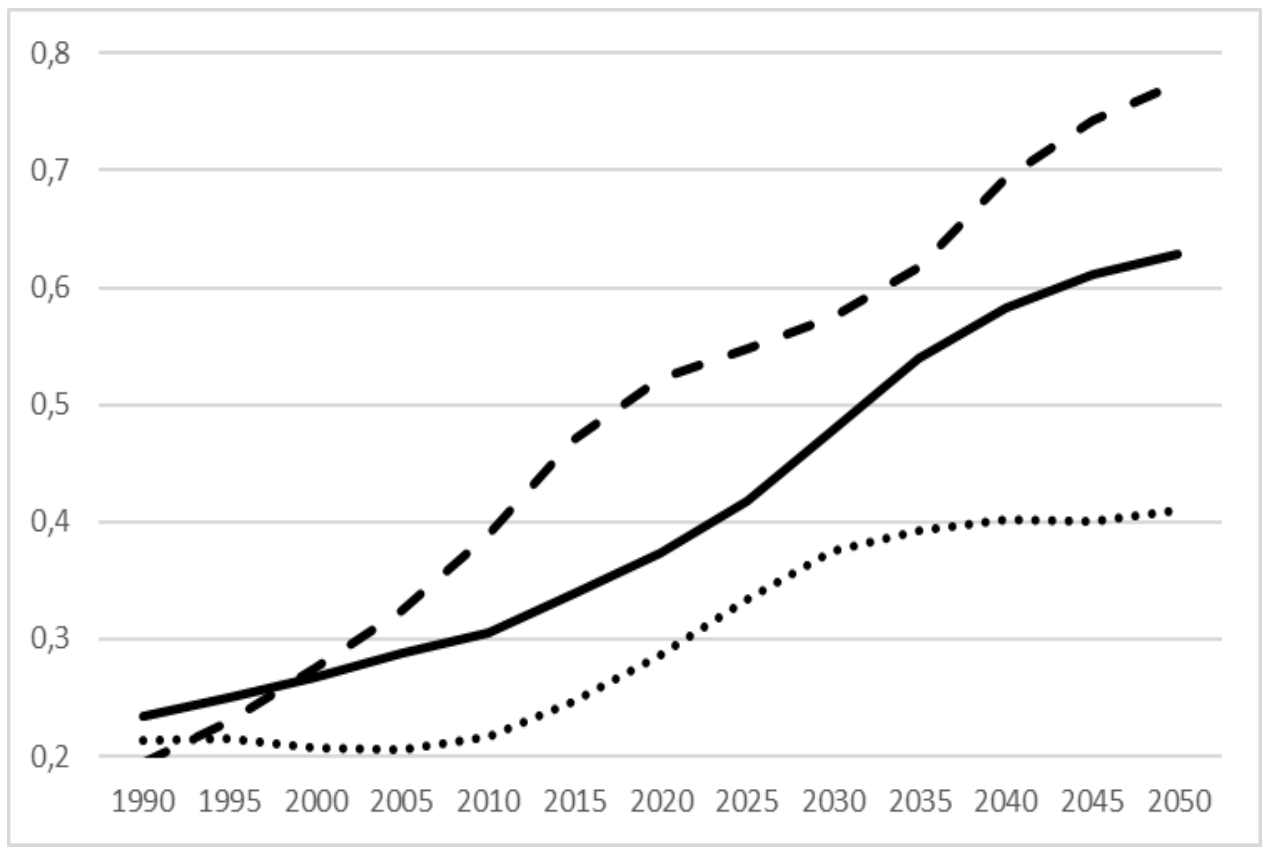

Source: United Nations population projections. Euro area, Japan (dashed) and US (dotted line). Old age dependency ratio is of population aged 65 or older divided by population aged between 20 and 64 . 
Table 1. Contribution of capital deepening and TFP to overall productivity growth

\begin{tabular}{|c|c|c|c|}
\hline \multicolumn{4}{|c|}{ Euro area } \\
\hline & Productivity & Capital Deepening & TFP \\
\hline $1990-95$ & 0.7 & 0.1 & 0.5 \\
\hline $1996-00$ & 1.0 & 0.9 & 0.1 \\
\hline 2001-05 & 0.5 & -0.1 & 0.6 \\
\hline $2006-10$ & 0.4 & -0.3 & 0.7 \\
\hline 2011-16 & 0.5 & -0.1 & 0.6 \\
\hline \multicolumn{4}{|c|}{ Japan } \\
\hline $1990-95$ & 1.3 & 0.1 & 1.2 \\
\hline $1996-00$ & 1.6 & 0.1 & 1.5 \\
\hline 2001-05 & 1.2 & -0.3 & 1.5 \\
\hline $2006-10$ & 0.4 & -1.2 & 1.7 \\
\hline 2011-16 & 0.6 & 0.9 & -0.3 \\
\hline \multicolumn{4}{|c|}{ US } \\
\hline $1990-95$ & 1.5 & 0.7 & 0.8 \\
\hline $1996-00$ & 2.5 & 2.4 & 0.1 \\
\hline 2001-05 & 1.8 & 0.7 & 1.1 \\
\hline $2006-10$ & 1.1 & -1.1 & 2.2 \\
\hline 2011-16 & 0.6 & 0.8 & -0.2 \\
\hline
\end{tabular}

Note: AMECO, EU Commission. Growth accounting exercise based on a Cobb-Douglas production function expressed in productivity terms, i.e. output per worker. Capital income share is set equal to one third, according to standard practices. 